\title{
Rola systemów depozytowo-zwrotnych (kaucyjnych) w organizacii recyklingu odpadów komunalnych w państwach Europy. Wykorzystanie automatów RVM (butelkomatów)
}

\author{
Role of Deposit Return Systems \\ in the Organisation of Municipal Waste Recycling in European Countries. \\ The use of RVMs
}

Streszczenie: Systemy depozytowo-zwrotne DRS (deposit refund/return systems) działają obecnie z powodzeniem w kilkunastu państwach Europy, podobne rozwiązania organizacyjno-rynkowe spotyka się w Stanach Zjednoczonych, Australii i innych krajach. Systemy tego typu wykorzystują mechanizm pobierania kaucji za zakup określonych dóbr i jej zwrotu w przypadku oddania przez klienta opakowania do sprzedawcy lub specjalnego punktu odbioru. Systemy DRS sprawiają także, że wzrasta poziom cyrkulacji materiałów i surowców w procesach recyklingowych i zmniejsza się tym samym poziom składowania odpadów. Elementem usprawniającym działanie tego typu systemów są automaty RVM (reverse vending machines) popularnie nazywane w Polsce „butelkomatami”. Systemy depozytowo-zwrotne prowadzą do wzrostu stopnia recyklingu odpadów komunalnych pochodzących z gospodarstw domowych. Różnią się jednak pod względem rozwiązań organizacyjnych i regulacyjnych w poszczególnych krajach. Celem artykułu jest zatem porównanie rozwiązań stosowanych w krajach Europy w obszarze DRS oraz dokonanie ich wstępnej typologii, przedstawienie korzyści i osiągnięć poszczególnych państw, a także trudności w implementacji takiego sposobu radzenia sobie z odpadami. W artykule wykorzystano informacje z raportów, dane statystyczne i wyniki badań firm konsultingowych oraz sprawdzania operatorów systemów depozytowo-zwrotnych.

\footnotetext{
Abstract: Deposit Refund/Return Systems (DRS) are currently operating successfully in several European countries, similar organisational solutions are found in the United States, Australia and other countries. Such systems use a mechanism of collecting a deposit for the purchase of certain goods and returning the deposit if the customer gives the packaging back to the seller or a special collection point. Such systems also increase the circulation of materials and raw materials in recycling processes and thus reduce the level of waste disposal. RVM machines (Reverse Vending Machines), popularly known in Poland as "bottling machines", are a popular element improving the operation of such organisational systems. Deposit and return systems are a common name for the way of organising and increasing the degree of recycling of waste, especially packaging waste from households. However, they differ in terms of organisational and regulatory solutions in individual countries. Therefore, the purpose of this article is to compare the solutions applied in the European countries in
} 
the area of returnable deposit systems, to make their typology, to present the benefits and achievements of individual countries and the difficulties in implementing such a way of dealing with waste. The article uses reports and statistical data, as well as the results of research conducted by consulting companies and checking operators of return depository systems.

Słowa kluczowe: butelkomaty; kaucja; odpady komunalne; odpady opakowaniowe; PET; recykling; system depozytowo-zwrotny

Keywords: deposit; deposit reverse system; municipal waste; packaging waste; PET; recycling; reverse vending machines; RVM

Otrzymano: 8 stycznia 2020

Received: 8 January 2020

Zaakceptowano: 29 kwietnia 2020

Accepted: 29 April 2020

Sugerowana cytacja / Suggested citation:

Rudewicz, J. (2020). Rola systemów depozytowo-zwrotnych (kaucyjnych) w organizacji recyklingu odpadów komunalnych w państwach Europy. Wykorzystanie automatów RVM (butelkomatów). Prace Komisji Geografii Przemysłu Polskiego Towarzystwa Geograficznego, 34(2), 50-70. doi 10.24917/20801653.342.4

\section{WSTĘP I KONTEKST}

Powstałe za sprawą współczesnej rewolucji konsumpcyjnej społeczeństwa konsumpcyjne, które wraz z podmiotami reprezentującymi podaż biorą udział w wymianie rynkowej na niespotykaną skalę, pozostają w dużej mierze nieświadome dalszego cyklu życia nabywanych przez siebie produktów. Mechanizm rynkowy, znajdujący nowe kanały dystrybucji i promocji, kreujący potrzeby nowych produktów, nie obejmuje kolejnych faz życia produktu, którym zazwyczaj w ostatniej fazie jest wytworzenie odpadu (Davies, 2017).

Rewolucja w konsumpcji nie przeniosła się dalej poza działanie rynku i pomija koszty zewnętrzne konsumpcji. Widoczne jest tu przesunięcie w czasie pomiędzy jej wzrostem a działaniami obejmującymi walkę z jej skutkami. Wiele społeczeństw krajów zachodnich podjęło walkę z efektami nieodpowiedzialnej konsumpcji, przejawiającej się znaczną produkcją odpadów komunalnych, wśród których dużą rolę odgrywają odpady opakowaniowe. Odpowiedzialność za opakowania dotyczy nie tylko konsumentów i państwa, ale wszystkich uczestników procesu wymiany. W procesie logistycznym opakowanie stanowi dodatkowy produkt pełniący funkcje marketingową, transportową i ochronną produktu.

W wielu krajach wdrożono na szeroką skalę systemy depozytowo-zwrotne. Takie systemy nie rozwiązują problemu nadmiaru odpadów, gdyż wysoka konsumpcja wymaga zmiany przyzwyczajeń konsumentów i podmiotów w łańcuchu dostaw. Wymaga zamiany wygodnych opakowań i wprowadzenia w to miejsce tworzyw biodegradowalnych - łatwych w recyklingu. Rosnąca konsumpcja i produkcja w Polsce, stawianie wysokich wymagań co do pozyskania i recyklingu odpadów opakowaniowych przez Unię Europejską oraz globalny megatrend związany z wdrażaniem wizji zero waste i circular economy (Hanaki, 2002; Ween, 2012), a także wzrost kosztów usług komunalnych dotyczących odpadów stawia nasz kraj w obliczu wyzwania, aby podjąć odpowiednie działanie. Systemy depozytowo-zwrotne w kształcie wdrożonym w Skandynawii czy Niemczech mogą przyczynić się - poprzez „ekonomizację” odpadu opakowaniowego do stopniowej poprawy sytuacji w naszym kraju. 
Celem artykułu jest wyjaśnienie i zdefiniowanie, czym jest system depozytowo-zwrotny i jakie są doświadczenia w jego funkcjonowaniu w krajach Europy. Kolejnym celem jest dokonanie wstępnej typologii systemów depozytowo-zwrotnych wraz z ich charakterystyką opartą na najlepszych przykładach. Chodzi o typologię wynikającą głównie z zasadniczych różnic w sposobie organizacji systemu DRS. Za cel trzeci obrano przedstawienie kilku aspektów ekonomicznych działania systemów depozytowo-zwrotnych. Zrealizowano go, podając przykłady z ogólnodostępnych raportów w zestawieniu tabelarycznym. Celem czwartym jest przestawienie perspektyw wdrożenia systemu DRS w Polsce. Oczywiste jest, że problematyka ta wykracza poza możliwości objętościowe artykułu, dlatego też będzie to zarys i główne przesłanki konieczności dostosowania naszego systemu zbioru odpadów do współczesnych wymagań i najlepszych wzorców.

System depozytowo-zwrotny (kaucyjny) (z ang. deposit refund system, DRS) w wąskim znaczeniu to zorganizowany sposób selektywnego zbioru odpadów oparty na mechanizmie depozytu (kaucji), składa się z wielu elementów (infrastruktura) i procedur ${ }^{1}$. W szerszym ujęciu to system organizacyjny wejścia i wyjścia, w którym opakowania zwrotne krążą w procesach, w których są ponownie wykorzystywane lub poddawane recyklingowi. W systemie tym obecne są dwa przeciwstawne strumienie, materiałowy i finansowy. Mechanizm systemu polega na powiązaniu materiału (opakowanie, zużyty produkt) i depozytu doliczanego do ceny detalicznej zakupu danego dobra oraz na zwrocie tej kwoty po oddaniu opakowania w odpowiednim miejscu. W obiegu finansowym między uczestnikami systemu krąży kaucja oraz refundacja kosztów z przychodów ze sprzedaży i opłat producenckich.

System depozytowo-zwrotny jest instrumentem niwelującym tzw. negatywne efekty zewnętrzne składowania odpadów i ich wpływ na zdrowie ludzi i ekosystemy ${ }^{2}$. Systemy te są stosowane w odniesieniu do takich produktów, jak: baterie, opony, olej samochodowy, elektronika użytkowa i palety magazynowe. Najczęściej stosuje się je do poprawy wskaźników recyklingu odpadów opakowaniowych z gospodarstw domowych, jak butelki $\mathrm{PET}^{3}$, puszki aluminiowe, butelki szklane.

Całość zagadnień związanych z systemami depozytowo-zwrotnymi można rozpatrywać z kilku przeplatających się płaszczyzn. Po pierwsze, od strony organizacji. W tej płaszczyźnie mieszczą się kwestie ról, zakresu działań i procesów właściwych dla uczestników systemu oraz jego sterowania. Kośćcem dla zarządzania lub kolejną płaszczyzną systemu DRS jest problematyka wprowadzenia odpowiedniej legislacji i rozwiązań prawnych. Dzięki nim znane są kompetencje, obowiązki i prawa podmiotów uczestniczących w systemie oraz zdefiniowane są same podmioty. Odpowiednie funkcjonowanie systemu depozytowo-zwrotnego to przepływy strumieni materiałowych i finansowych, obieg informacji, zatem tworzy to płaszczyznę zagadnień logistycznych i informatycznych.

Samo funkcjonowanie systemów DRS opiera się na zasadzie sztucznej ekonomizacji dla do tej pory jej pozbawionej konsumpcji. Polega to na ekonomicznym (i psychologicznym) mechanizmie gratyfikacji, dodatkowych bodźcach motywacyjnych do oddania opakowania w zamian za zwrot kaucji lub inne (zwykle drobne) benefity. Kolejną

\footnotetext{
${ }^{1}$ W literaturze anglojęzycznej określa się je również jako sustainable waste management system, reverse logistic, network design in plastic industry, container deposit system (CDS).

2 Podatek Pigou (Hołuj, 2018).

3 Politereftalan etylenu.
} 
płaszczyzną - polem problematyki - są kwestie ekonomiczne związane z funkcjonowaniem DRS. Chodzi głównie o koszty - miejsca generowania kosztów, elementy systemu generujące przychody, opodatkowanie i finansowanie systemu, wycena efektów jego działania. Do tego zestawu należy dodać jeszcze techniczne aspekty ważnego, choć nieobligatoryjnego elementu systemu, jakim są butelkomaty, czyli automaty zwrotne. Obok tych kwestii istotne są również społeczne implikacje działania takich systemów, ich wpływ na świadomość konsumentów, skłonność do zwrotu opakowań i zmiany zachowania.

Polska, będąc członkiem Unii Europejskiej, zobowiązana jest do stosowania się do postanowień zawartych w dyrektywach unijnych. W kwestii odpadów Unia dąży do modelu gospodarki o obiegu zamkniętym (circular economy). Pojęcie to ma związek z metabolizmem cyklicznym w opozycji do metabolizmu liniowego w ujęciu systemowym (ekologicznym) lub miejskim. W tym przypadku „metabolity” to również odpady komunalne w części generowanej przez podmioty gospodarcze i gospodarstwa domowe. Zamieniane, przetwarzane - są one sztucznie metabolizowane na kolejne produkty i krążą w obiegu. Minimalizuje się w ten sposób masę i oddziaływanie odpadów, dąży się do jak największej neutralności wobec środowiska przyrodniczego i zdrowia człowieka (Rogers, 1997; Badcock, 2002; Beatley, 2012; Moir, Moonen, Clark, 2014, Rudewicz, 2019).

Unia podejmuje wiele działań politycznych i legislacyjnych na polu redukcji emisji gazów cieplarnianych, oszczędzania zasobów, zmniejszenia oddziaływania konsumpcji na środowisko, przy jednoczesnym zapewnieniu konkurencyjności gospodarki i tworzenia nowych miejsc pracy. W UE podkreślana jest rola projektowania nowych produktów, uwzględniająca ich oddziaływanie w ekosystemach po okresie użytkowania oraz ich efektywność energetyczną. Ważną kwestią jest dostępność części zamiennych, łatwość napraw i przetwarzania produktów wycofanych z eksploatacji. Komisja Europejska zleciła organizacjom normalizacyjnym opracowanie kryteriów służących do pomiaru trwałości, przydatności do ponownego użycia, napraw, możliwości recyklingu i obecności surowców krytycznych. Kryteria te powinny być stosowane w istniejących i nowych normach.

W Dzienniku Urzędowym Unii Europejskiej zostały opublikowane cztery dyrektywy zmieniające dotychczasowe przepisy regulujące gospodarkę odpadami w Unii. Dyrektywy weszły w życie 4 lipca 2018 roku, teraz państwa członkowskie wdrażają je do przepisów krajowych. Są to następujące akty prawne:

- dyrektywa Parlamentu Europejskiego i Rady (UE) 2018/852 z dnia 30 maja 2018 roku zmieniająca dyrektywę 94/62/WE w sprawie opakowań i odpadów opakowaniowych;

- dyrektywa Parlamentu Europejskiego i Rady (UE) 2018/851 z dnia 30 maja 2018 roku zmieniająca dyrektywę 2008/98/WE w sprawie odpadów;

- dyrektywa Parlamentu Europejskiego i Rady (UE) 2018/850 z dnia 30 maja 2018 roku zmieniająca dyrektywę 1999/31/WE w sprawie składowania odpadów;

- dyrektywa Parlamentu Europejskiego i Rady (UE) 2018/849 z dnia 30 maja 2018 roku zmieniająca dyrektywy 2000/53/WE w sprawie pojazdów wycofanych z eksploatacji, 2006/66/WE w sprawie baterii i akumulatorów oraz zużytych baterii i akumulatorów i 2012/19/UE w sprawie zużytego sprzętu elektrycznego i elektronicznego. 
Ważnym aktem prawnym jest również nowsza dyrektywa dotycząca tworzyw sztucznych - dyrektywa Parlamentu Europejskiego i Rady (UE) 2019/904 z dnia 5 czerwca 2019 roku w sprawie zmniejszenia wpływu niektórych produktów z tworzyw sztucznych na środowisko.

Wymienione akty prawne wpisują się w hasło zero waste i circular economy gospodarka o obiegu zamkniętym. Komisja Europejska wdraża także w ramach dyrektyw system monitorowania obiegu odpadów oraz prowadzi inicjatywę Circular Plastics Alliance. Jest ona podobna w założeniach do deklaracji New Plastic Economy o zasięgu globalnym (więcej w: The New Plastic Economy, 2016; Declaration of the Circular Plastics Alliance, 2018). Obejmuje najważniejsze ogniwa produkcji tworzyw sztucznych oraz cały cykl życia tworzyw sztucznych - od konsumenta po przedsiębiorstwa recyklingowe, od pierwotnych producentów, aż po przetwórców i sprzedawców detalicznych.

Dla Polski bardzo ważne są zapisy dyrektywy ramowej UE w sprawie odpadów (art. 11). Zgodnie z nimi państwa członkowskie UE będą zobowiązane do 2025 roku recyklingować 55\% odpadów komunalnych, do 2030 roku - 60\%, a do 2035 roku - 65\%. Co więcej, UE wprowadziła wyższe limity w zakresie recyklingu opakowań i tworzyw sztucznych. Co najmniej 65\% z nich musi być poddane recyklingowi przed 2025 rokiem, a 70\% do 2030 roku. W treści dyrektyw podkreślano, że odpady komunalne stanowią w przybliżeniu od 7 do $10 \%$ wszystkich odpadów wytwarzanych w Unii. Jest to jednak jeden z najbardziej złożonych strumieni odpadów, a sposób gospodarowania nimi świadczy zasadniczo o jakości całego systemu gospodarowania odpadami w danym państwie.

W przypadku poszczególnych frakcji odpadów opakowaniowych do roku 2025 i 2030 musi być poddane recyklingowi odpowiednio 50 i 55\% opakowań z tworzyw sztucznych. W przypadku opakowań drewnianych jest to odpowiednio 25 i 30\%, opakowań z metali żelaznych - 70 i 80\%, opakowań aluminiowych - 50 i 60\%, opakowań szklanych - 70 i 75\%, a opakowań papierowych i kartonowych - 75 i 85\%. Przepisy unijne przewidują też, że wprowadzane na rynek butelki na napoje typu PET mają zawierać materiały pochodzące z recyklingu, tzw. recyklat. Dyrektywa UE ograniczająca zużycie jednorazowych produktów z tworzyw sztucznych mówi o minimalnym 30 -procentowym udziale w tych opakowaniach recyklatu z tworzyw sztucznych do 2030 roku.

Wyzwania związane z gospodarowaniem odpadami komunalnymi wynikają z ich wysoce złożonego i zróżnicowanego składu, bezpośredniego sąsiedztwa miejsc pobytu ludności, dużej widoczności (estetyka), a także oddziaływania na środowisko i zdrowie ludzkie. Dyrektywa określa również możliwość stosowania zasady „zanieczyszczający płaci” wobec producentów opakowań: „Koszty gospodarowania odpadami, w tym koszty związane z niezbędną infrastrukturą i jej eksploatacją, ponosi pierwotny wytwórca odpadów lub obecny bądź poprzedni posiadacz odpadów" (dyrektywy nr 2018/851 i 2018/852).

Według raportu Komisji Europejskiej (Report..., 2019) w Europie zwiększył się recykling odpadów komunalnych w latach 2008-2016, a udział materiałów pochodzących z recyklingu w ogólnym zapotrzebowaniu na materiały wzrasta. Jednak wartość ogółem - około 12\% wkładu materiałowego tworzywa z recyklingu - nie jest imponująca. 


\section{PROBLEM ODPADÓW OPAKOWANIOWYCH W POLSCE NA TLE PAŃSTW UE I EFTA}

Ze względu na złożoność całego wolumenu odpadów, generowaną przez działalność produkcyjną i bytową człowieka, w artykule stosuje się podejście od strony konsumpcyjnej. Odpady opakowaniowe zaliczane są do odpadów komunalnych. Termin „odpady komunalne” mówi o odpadach powstających w gospodarstwach domowych z nieprzemysłowej działalności człowieka ${ }^{4}$. Do odpadów komunalnych zalicza się również te pochodzące od innych wytwórców, ale mające charakter i skład podobny do odpadów produkowanych $\mathrm{w}$ gospodarstwach domowych - z wykluczeniem odpadów niebezpiecznych. Mowa tu o innych podmiotach generujących odpady, np. w działalności handlowej, produkcyjnej. Odpady można kwalifikować na podstawie różnych kryteriów, takich jak ich pochodzenie, szkodliwość (dla ludzi i przyrody), stan skupienia, skład chemiczny, zawartość materii organicznej, przydatność do dalszego przetworzenia i wykorzystania (ustawa o odpadach z dnia 14 grudnia 2012 roku).

Odpady komunalne charakteryzują się dużą zmiennością w ciągu roku. Są również niejednorodne, jeśli chodzi o skład surowcowy, a także niestabilne, np. podatne na gnicie. Mogą stanowić zagrożenie skażeniem oraz zawierać odpady niebezpieczne. Zgodnie ze Wspólnym Systemem Segregacji Odpadów (WSSO/JSSO) ${ }^{5}$ odpady komunalne podlegają podziałowi na cztery podstawowe frakcje: papier, metal i tworzywa, szkło i odpady bio. Tylko część z tych frakcji to odpady opakowaniowe, podlegające działaniu sytemu depozytowo-zwrotnego. W tabeli 1 zaprezentowano roczną produkcję odpadów opakowaniowych w krajach UE i EFTA w gospodarstwach domowych. W tabeli zawarta jest też struktura wagowa poszczególnych frakcji odpadów opisanych wyżej. Wśród odpadów dominuje papier i karton (41\%), następnie szkło i plastik (18\%), drewno (15\%), mniej jest metali - nieco ponad $5 \%$.

Tabela 1. Produkcja i struktura (wagowa) odpadów opakowaniowych z gospodarstw domowych w UE i EFTA w 2015 roku.

\begin{tabular}{|l|c|c|}
\hline \multicolumn{1}{|c|}{ Frakcje odpadów } & W tonach & Struktura \\
\hline Odpady opakowaniowe & 84571308 & $100,00 \%$ \\
\hline Papier i karton & 34797307 & $41,15 \%$ \\
\hline Plastik & 15888042 & $18,79 \%$ \\
\hline Drewno & 13271836 & $15,69 \%$ \\
\hline Metale & 4558664 & $18,72 \%$ \\
\hline Szkło & 15832316 & $0,26 \%$ \\
\hline Inne & & \\
\hline
\end{tabular}

Źródło: opracowanie na podstawie danych Eurostatu

Stosunkowo duży udział papieru i drewna ma pewną pozytywną właściwość, gdyż są to materiały biodegradowalne. Według danych z lat 2006-2016 dla UE 27 zarówno wolumen, jak i struktura odpadów opakowaniowych nie uległy istotnym zmianom. Gdy przyjrzeć się danym o produkcji odpadów opakowaniowych per capita od 2006

\footnotetext{
${ }^{4}$ Inne ich określenie to odpady bytowe.

${ }^{5}$ Na mocy rozporządzenia Ministra Środowiska z dnia 29 grudnia 2016 roku w Polsce wprowadzony został Wspólny (Jednolity) System Segregacji Odpadów. Zgodnie z tym prawem od 1 lipca 2017 roku na terenie całej Polski obowiązują identyczne zasady selektywnej zbiórki.
} 
do 2016 roku, w całej Unii wzrost wyniósł 2,2\% - do 166 kg na osobę. W tym samym horyzoncie czasowym o 17\% wzrósł odzysk, ze $112 \mathrm{~kg}$ na osobę do $130 \mathrm{~kg}$ oraz o 18\% wzrósł poziom recyklingu - z 92 do 109 kg na osobę. Odzysk w 2016 roku wyniósł 79\%, a recykling $65 \%$ masy opakowań.

W ustawie z dnia 14 grudnia 2012 roku o odpadach przez odzysk rozumie się jakikolwiek proces, którego celem jest wykorzystanie części lub całości odpadów albo odzyskania z nich substancji, materiałów, energii i ich powtórne wykorzystanie. Są to działania, które w żaden sposób nie zagrażają życiu i zdrowiu oraz nie szkodzą środowisku.

Odzysk stanowi szerszą kategorię niż recykling. Za recykling uważa się czynności, których celem jest odzyskanie i ponowne wykorzystanie odpadów komunalnych, przy możliwie jak najmniejszym nakładzie energii. Podstawowym założeniem recyklingu jest staranna selekcja odpadów, przetworzenie na nowe produkty i ponowne, maksymalne ich wykorzystanie (recykling materiałowy, surowcowy, organiczny). Recykling nie obejmuje odzyskiwania energii i ponownego przetwarzania na materiały (używa się czasem określenia recykling termiczny), które mają być wykorzystane w charakterze paliwa, co odróżnia go od odzysku (Chakrabarti, 2014).

W państwach Unii Europejskiej i krajach EFTA relacja odzysk i recykling oraz produkcja odpadów opakowaniowych kształtuje się w sposób zróżnicowany. Geograficzne zróżnicowanie tych wielkości na osobę oraz dynamikę zmian za okres 2008-2017 zaprezentowano na kartodiagramie (rycina 1).

W 2017 roku najwięcej odpadów opakowaniowych na osobę generowali mieszkańcy Luksemburga - 233 kg, Niemiec - 227 kg i Irlandii - 217 kg. Powyżej 200 kg na osobę odnotowuje się produkcję odpadów opakowaniowych we Włoszech. Polski konsument wytwarzał $157 \mathrm{~kg}$ na osobę w 2017 roku, jest to poziom zbliżony do Austrii i Belgii oraz Islandii. Najmniejsze wartości, rzędu 60-70 kg, notują takie kraje, jak Grecja, Chorwacja, Cypr, Słowacja, Bułgaria. Największą dynamiką w produkcji odpadów opakowaniowych na osobę w latach 2008-2017 charakteryzowały się kraje Europy Wschodniej (np. Polska 40\%, Słowacja 60\%), z wyjątkiem państw bałtyckich, Niemcy i - co zaskakujące na tle pozostałych państw skandynawskich - Norwegia. Pozostałe państwa charakteryzuje wytracenie dynamiki lub nawet redukcja generowanych odpadów opakowaniowych (np. Hiszpania, Grecja, Szwecja, Portugalia, Cypr, Łotwa).

Odzysk odpadów zobrazowany na rycinie 2 ukazuje wskaźnik odzysku odpadów opakowaniowych w 2015 roku. Wyraźnie widać tu sytuację, w której państwa Europy Wschodniej znajdują się w najniższym wartościowo przedziale klasowym 41,3-56,4\% i 56,4-72,7\%, poniżej średniej dla UE i EFTA wynoszącej 79\%. Powyżej tej wartości znajdują się m.in. Finlandia - 102\% (może to oznaczać, że kraj ten nie tylko odzyskuje swoje, ale też importuje odpady i przetwarza u siebie). Wysokim wskaźnikiem odzysku mogą pochwalić się kraje Beneluksu, Niemcy, Norwegia, Irlandia, Szwecja, Dania, Austria.

Rycina 3 uzupełnia obraz odzysku odpadów opakowaniowych w UE i krajach EFTA. Dzięki kartodiagramowi możemy zauważyć, że w zdecydowanej większości krajów rośnie stopień odzysku odpadów opakowaniowych na przestrzeni porównywanych lat 2008-2017. Największe przyrosty, czyli poprawę sytuacji, obserwuje się wśród nowych członków Wspólnoty Europejskiej - w Estonii, Słowacji, Bułgarii i Polsce. Zmniejszenie odzysku odpadów opakowaniowych zauważalne jest w Szwecji, Portugalii, ale w krajach tych zmniejszyła się również produkcja odpadów. 
Rycina 1. Odpady opakowaniowe w UE i EFTA na osobę w latach 2008-2017 oraz dynamika zmian w produkcji tych odpadów w tym okresie (przedziały według metody Jenksa)

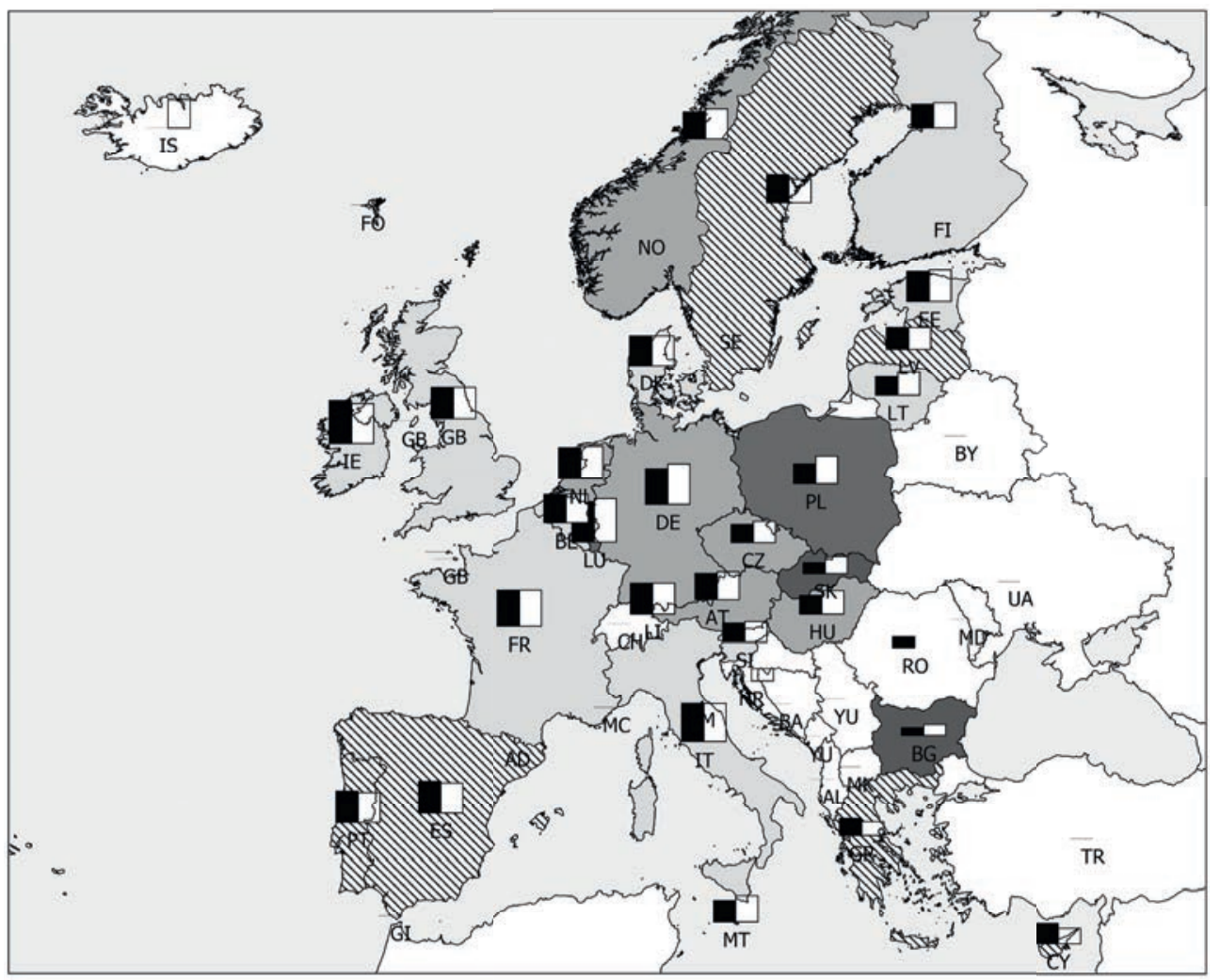

Odpady opakowaniowe z gospodarstw domowch na osobę w kg

Packaging waste from households per capita [kg]

240

2008

Niepełne dane

Dynamika zmian w prod. odpadów opakowaniowych z gospodarstw dom. 2008 - 2017

Dynamics of changes in the generate domestic pack. waste 2008 - 2017

口 0,499 f 0,593 (2)

0,321 of 0,499 (3)

0,128 of 0,321 (6)

0 of 0,128 (11)

$\mathbb{\mathbb { N }}-0,251$ of $0 \quad$ (6)

Źródło: opracowanie i obliczenia własne na podstawie danych Eurostatu 
Rycina 2. Wskaźnik odzysku odpadów opakowaniowych w UE i EFTA w 2015 roku. Przedziały klasowe wyznaczone metodą przerw naturalnych Jenksa

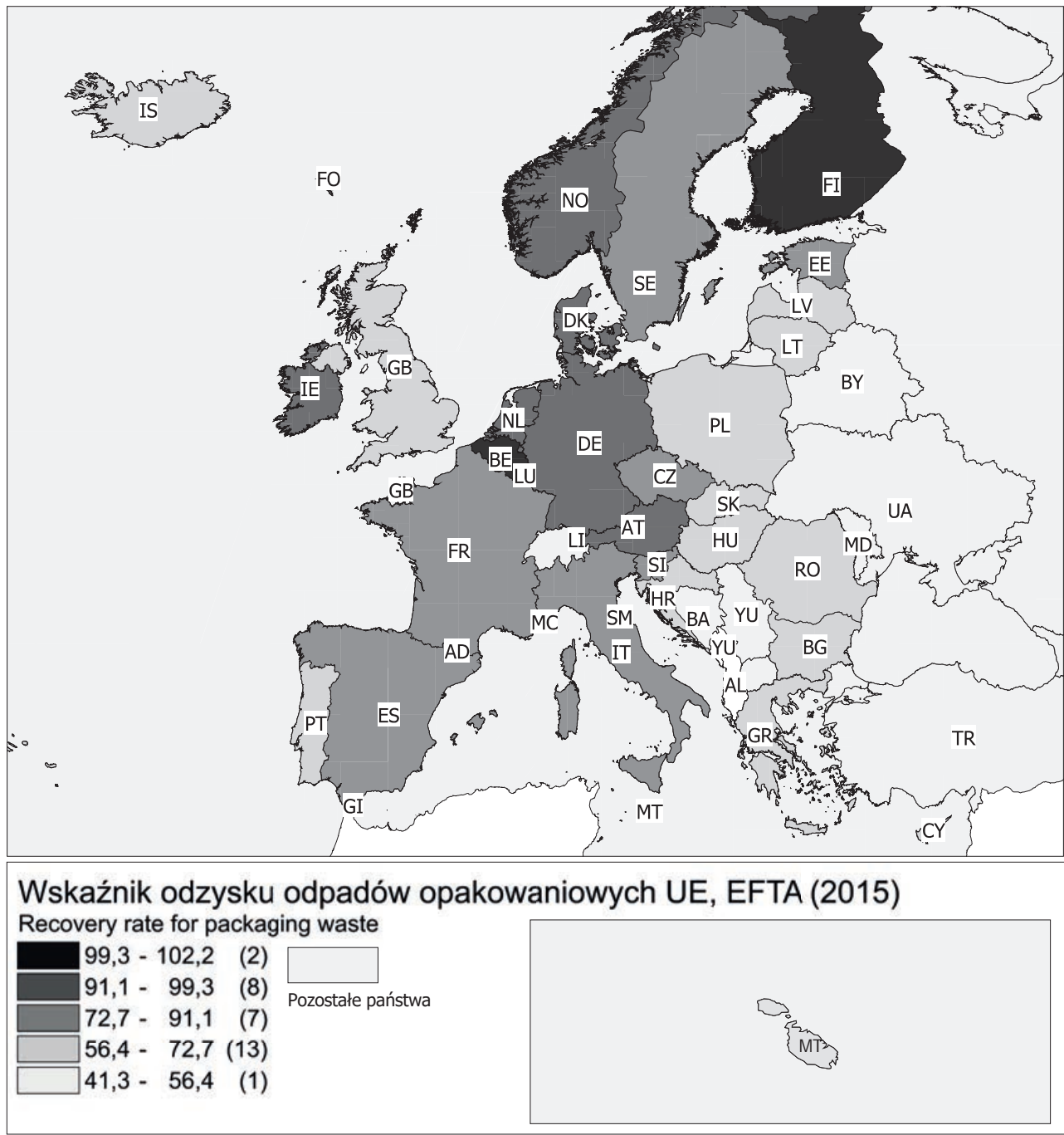

Źródło: opracowanie własne na podstawie danych Eurostatu 
Rycina 3. Odpady opakowaniowe na mieszkańca - porównanie sytuacji w 2008 i 2017 roku

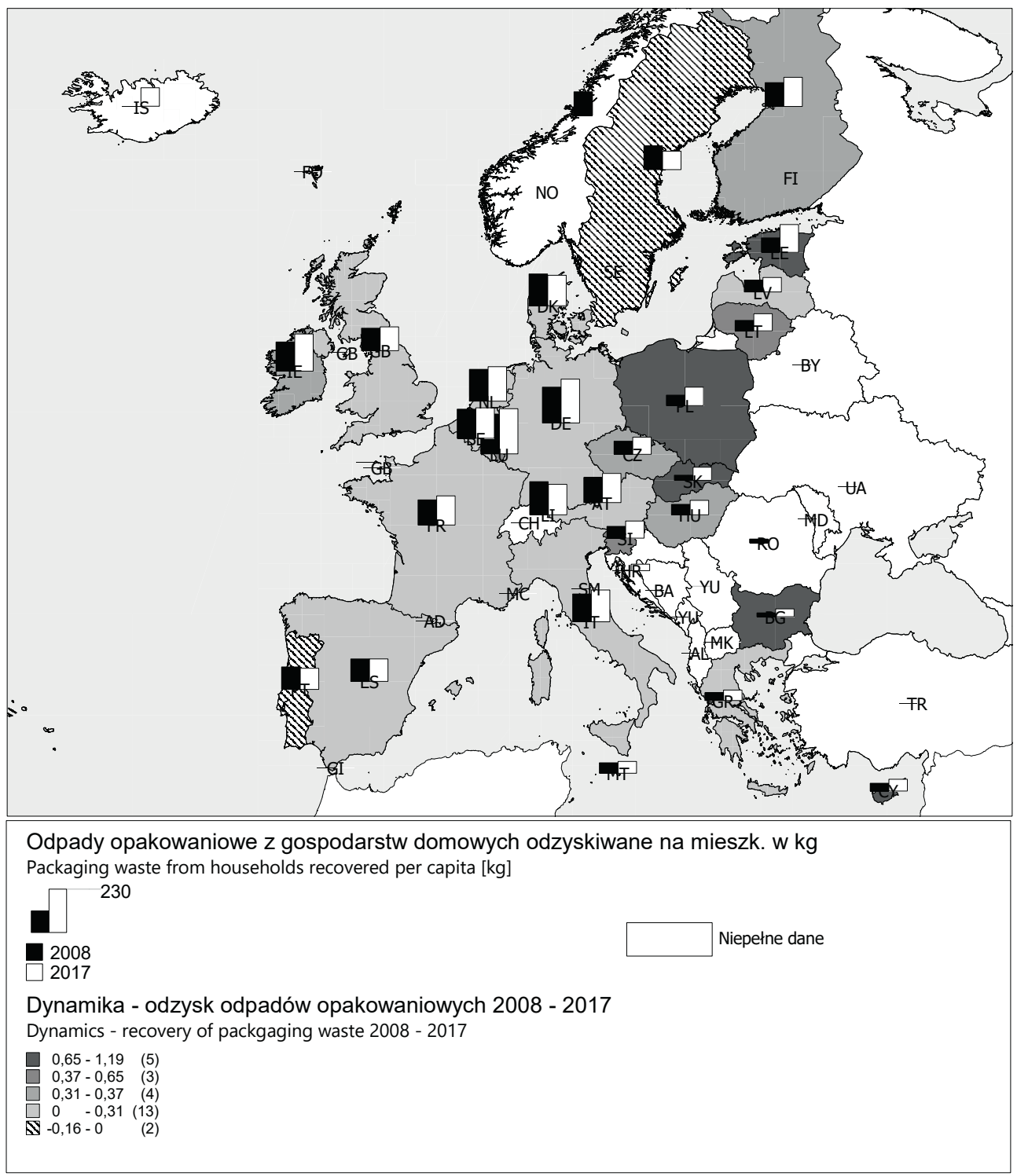

Źródło: opracowanie własne na podstawie danych Eurostatu

Interesująca dla problematyki artykułu jest relacja pomiędzy generowaniem odpadów w gospodarstwach domowych a recyklingiem, procesem wydajniejszym od odzysku z puntu widzenia korzyści środowiskowych. Na rycinie 4 przedstawiono tę relację dla krajów UE i EFTA. Widzimy z niej, że najzamożniejsze kraje generują najwięcej odpadów per capita, co naturalnie wynika z wysokiego poziomu konsumpcji. Wśród nich największym udziałem recyklingu w proporcji do produkcji odpadów opakowaniowych wyróżniają się kraje skandynawskie oraz kraje Beneluksu. Spośród państw Europy Środkowej i Wschodniej wyróżnia się Estonia ze względu na generowane w kilogramach odpady oraz stopień recyklingu. 
Rycina 4. Ilość wszystkich odpadów opakowaniowych wytworzonych i poddanych recyklingowi w przeliczeniu na mieszkańca państw UE i wybranych krajów EFTA w 2015 roku, w kilogramach

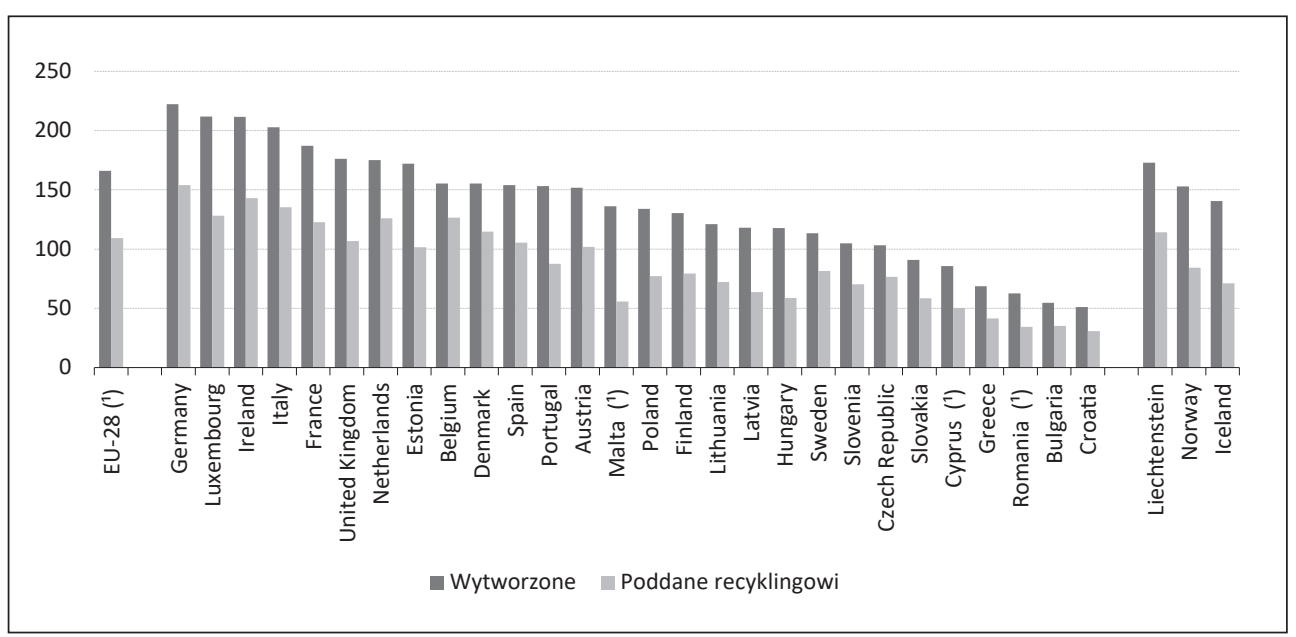

Źródło: Eurostat

Na podstawie danych z ryciny 4 i pozostałych rycin można stwierdzić, że sprawdza się teza mówiąca o tym, że kraje Europy Wschodniej generują per capita mniej odpadów. Te państwa różnie radzą sobie w organizacji recyklingu i odzysku. Moment, w którym znalazły się wyżej w rozwoju gospodarczym i niestety pod względem poziomu konsumpcji ich obywateli, jest odpowiedni na to, żeby wprowadzić na swoim terytorium systemy depozytowo-zwrotne w celu podniesienia stopnia recyklingu i odzysku. Dodatkowo kraje te powinny dążyć do zmian polegających na odchodzeniu od pakowania produktów w opakowania $\mathrm{z}$ frakcji trudnych do recyklingu.

\section{SYSTEMY DEPOZYTOWO-ZWROTNE - CHARAKTERYSTYKA}

Systemy depozytowo-zwrotne DRS, zdefiniowane we wprowadzeniu do artykułu, funkcjonują w wielu krajach (częściowo w Polsce). Jednak w skali i kształcie odpowiadających masowej konsumpcji działają w 10 krajach Europy: Norwegii, Finlandii, Szwecji, Islandii, Estonii, Holandii, Litwie, Chorwacji, Niemczech. Rozpoczęły się prace wdrożeniowe takich systemów w Czechach i Portugalii. W pozostałych krajach trwają prace pilotażowe i rozważania nad ich wprowadzeniem - por. rycina 5.

Generalną różnicą między systemami DRS w poszczególnych państwach jest sposób ich organizacji. W Europie dominuje typ scentralizowany, w którym nadrzędną rolę w systemie odgrywa tzw. operator. Jest to podmiot publiczny regulujący działanie systemu, posiadający bazę danych parametrów systemu, np. relacje sprzedane produktyodzysk, i bieżące informacje o jego działaniu. Spotykane są też systemy zdecentralizowane (głównie poza Europą), gdzie nie ma operatora, a zasady pobierania kaucji i zbiórki odpadów opakowaniowych są realizowane na podstawie umów i porozumień. Te dwa wymienione typy są dobrze opisane w literaturze - w raportach, trzeci typ został wyszczególniony na podstawie obserwacji autora. Są to próby samodzielnego instalowania automatów RVM przez miasta i jednostki samorządu terytorialnego. Skala ich działania jest niewielka, powstają one głównie za sprawą oddolnych inicjatyw. 
Rycina 5. Systemy depozytowo-zwrotne w Europie (scentralizowane i zdecentralizowane), państwa wdrażające systemy DRS. Stan na rok 2019

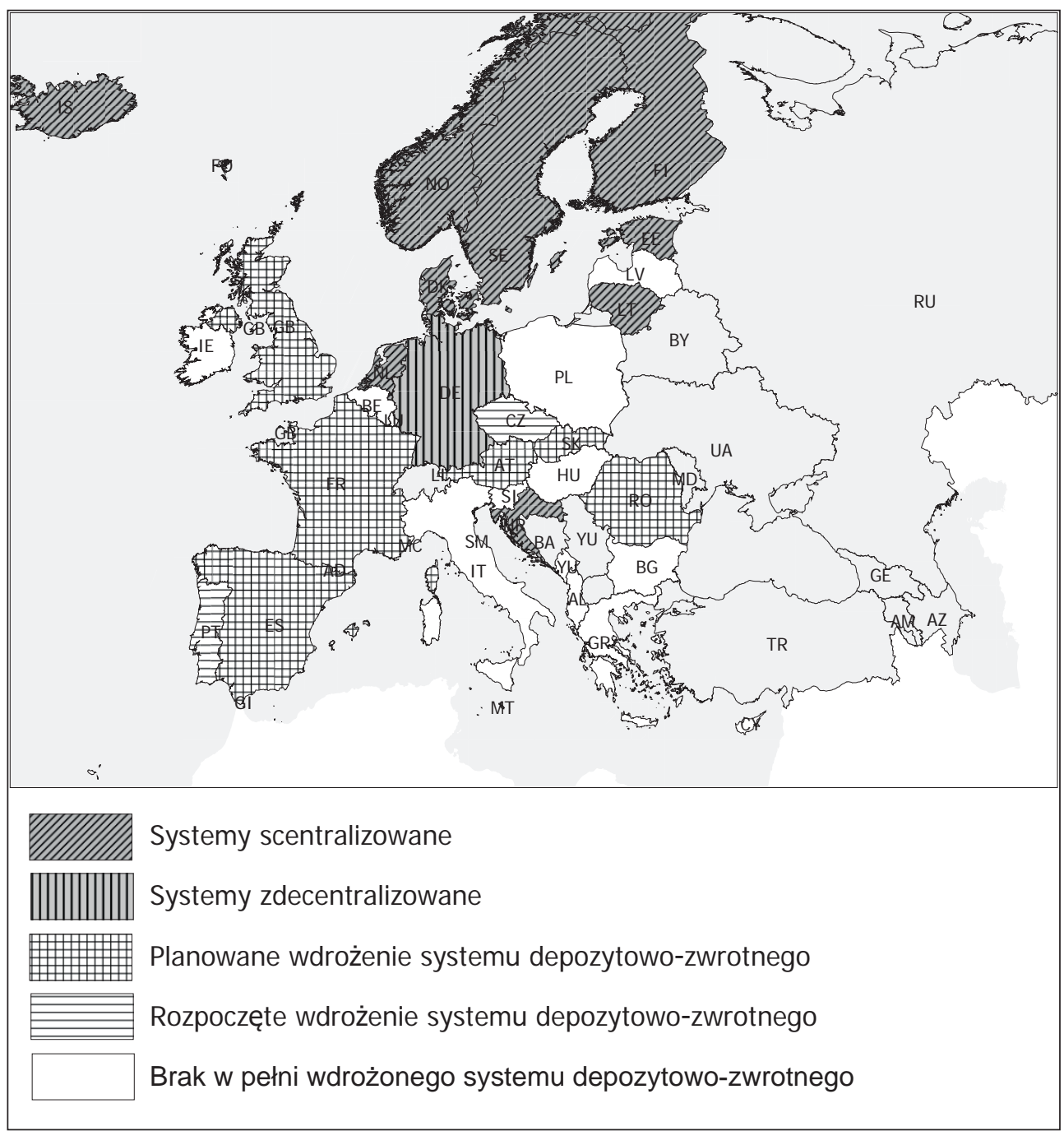

Źródło: opracowanie własne

Istnieją dwa główne sposoby postępowania z odpadami opakowaniowymi w oparciu o pobieranie za nie kaucji, głównie pozostających po napojach bezalkoholowych i piwie. Jest to ponowne napełnianie (zwykle za kaucją) - butelki (u producenta), płukane, uzupełniane i transportowane z powrotem do punktów sprzedaży. Szklane butelki wielokrotnego użytku mogą być napełniane ponad 50 razy, butelki PET wielokrotnego napełniania - do 20 razy. Istnieje też kaucja jednokierunkowa - butelki i puszki są używane przez klienta tylko raz, producent może odzyskać surowiec (recyklat) lub trafią one bezpośrednio do podmiotu zajmującego się recyklingiem, który wyprodukuje nowe butelki. Muszą one być ponownie napełnione i przetransportowane do klienta (Balcers, Brizga, Moora, Rall, 2019). 
Systemy depozytowo-zwrotne funkcjonujące w krajach Europy, wykorzystujące automaty zwrotne RVM służą do odbioru opakowań z plastiku, szkła i aluminium. Są to opakowania standaryzowane $\mathrm{w}$ danym kraju. Zbiórce nie podlegają opakowania tzw. tetra-pack, składające się z warstw papierowej, plastikowej i aluminiowej - wykorzystywane do pakowania m.in. mleka i soków. Butelki po środkach chemicznych i kosmetykach nie są objęte tym systemem zbiórki, nie stosuje się też kaucji dla butelek po winie i innych alkoholach oraz butelek o niskich lub wysokich pojemnościach - z powodu trudności ze standaryzacją.

W tabeli 2 zawarto zbiór podstawowych informacji o aktualnie działających systemach depozytowo-zwrotnych w Europie. Najwcześniej zainicjowanymi systemami DRS są systemy: szwedzki - w 1984 roku, islandzki - w 1989 roku, niemiecki - w 1991 roku, fiński - w 1996 roku, norweski - w 1999 roku i duński - w 2000 roku. A zatem największe doświadczenia w zakresie wprowadzenia systemów depozytowo-zwrotnych mają kraje skandynawskie i Niemcy. Okres przejściowy od inicjacji systemu do jego pełnego startu trwał zazwyczaj około dwóch lat lub był podzielony na etapy. Państwa stosujące DRS osiągnęły bardzo wysokie wskaźniki recyklingu odpadów opakowaniowych, trudne do osiągnięcia innymi sposobami (Fletcher, Hogg, Eye, Elliott, Bendali, 2012). Uśrednione wskaźniki recyklingu (szkło, aluminium, PET) wynoszą powyżej 90\%. Doświadczenia państw stosujących DRS mówią o wpływie wysokości kaucji na poziom recyklingu. Im jest on wyższy, odpowiednio wysoki w proporcji do siły nabywczej, tym większa skłonność konsumentów do podjęcia wysiłków w celu zwrotu opakowania. Na przykład w Niemczech poziom kaucji równy 25 eurocentom przewyższa cenę niektórych napojów (Cordle i in., 2019).

Systemy depozytowo-zwrotne w krajach przywołanych w tabeli 2 funkcjonują z wykorzystaniem automatów zwrotnych RVM (reverse vending machine). Inne nazwy spotykane w literaturze specjalistycznej dla tych urządzeń to: empty container return and handling machine, redeem machines, recycling returns machines, recyklomaty. Pierwszy patent na działającą maszynę do zwrotu i obsługi pustych kontenerów z funkcją zwrotu monet został złożony w USA 13 września 1920 roku przez Elmera M. Jonesa i Sue Walker Vancea. Z kolei pierwsza działająca maszyna do zwrotu butelek została wynaleziona i wyprodukowana przez firmę Wicanders ze Szwecji, wykorzystano ją pod koniec lat pięćdziesiątych XX wieku. W 1962 roku Aage Tveitan zaprojektował zaawansowaną automatyczną maszynę do zwrotu butelek, a jego firma Arthur Tveitan ASA wyprodukowała w Norwegii pierwsze instalacje. Reverse vending jest technologią sprawdzoną, używaną od ponad pięciu dekad. Obecnie wprowadza się na rynek jej piątą generację (The History..., 2013).

Urządzenia te posiadają obecnie zgniatarki dla większej pojemności zbieranych odpadów, wyposażone są w łączność internetową, dzięki której mogą przesyłać dane o liczbie przyjętych opakowań i kwocie zwróconej kaucji. Urządzenie skanuje kod kreskowy i wymiary opakowania, np. butelki PET, na tej podstawie kwalifikuje odpad do zwrotu kaucji. Zwrot odbywa się na różne sposoby, może być to wydruk paragonu upoważniający do odbioru pieniędzy w punkcie handlowym lub redukujący kwotę zakupów. Stosuje się też inne gratyfikacje (patrz system municypalny). Przeciętne urządzenie zajmuje powierzchnię około 4 mkw., wymaga zasilania elektrycznego, spotyka się instalacje powiększone o specjalne pomieszczenia magazynowe, a nawet zespolone w bloki baterie takich urządzeń w celu uniknięcia kolejek. Umiejscawiane są głównie w pobliżu punktów handlowych, na stacjach benzynowych, w ekoportach, rzadziej na 


\begin{tabular}{|c|c|c|c|c|c|c|c|c|c|c|}
\hline 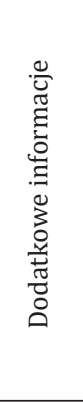 & 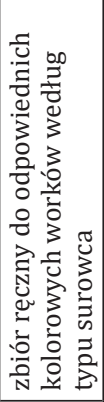 & 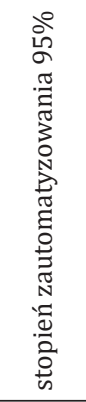 & 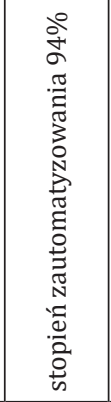 & 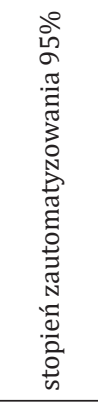 & 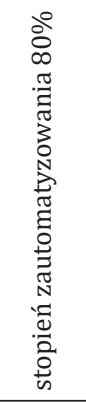 & 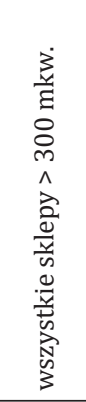 & 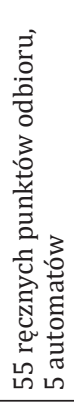 & 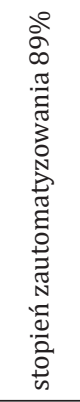 & 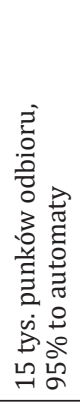 & 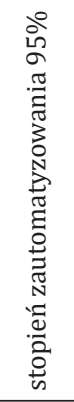 \\
\hline 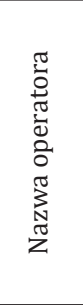 & 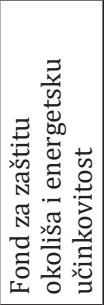 & 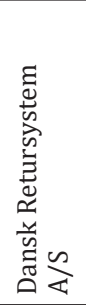 & 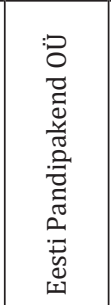 & 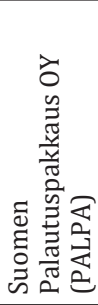 & 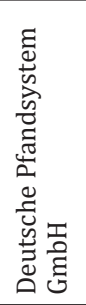 & 莺 & 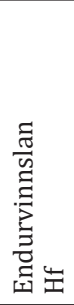 & 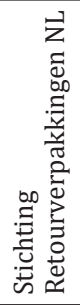 & 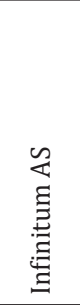 & 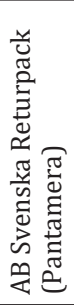 \\
\hline 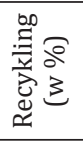 & ஃ & 느 & $\begin{array}{c}\text { m. } \\
\text { D. }\end{array}$ & $\begin{array}{l}\text { o } \\
\text { }\end{array}$ & s̀ & $\underset{N}{*}$ & ৪ & 느 & 으 & $\begin{array}{l}\infty \\
\infty\end{array}$ \\
\hline $\begin{array}{l}\frac{\pi}{\pi} \\
\frac{\pi}{\pi} \\
\sum\end{array}$ & 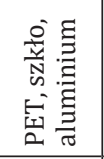 & 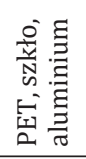 & 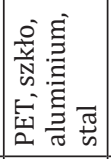 & 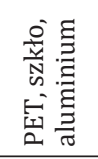 & 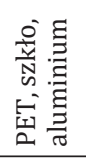 & 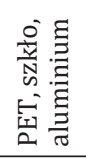 & 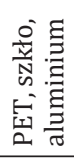 & 武 & 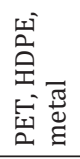 & 志荨 \\
\hline 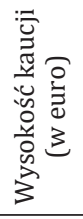 & $\begin{array}{l}0 \\
:\end{array}$ & $\begin{array}{l}0 \\
+ \\
0 \\
0 \\
0 \\
0 \\
0 \\
\text { - } \\
\stackrel{-}{0}\end{array}$ & $\begin{array}{l}0 \\
\stackrel{1}{0} \\
0\end{array}$ & 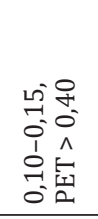 & $\begin{array}{l}\stackrel{L}{N} \\
\stackrel{0}{0}\end{array}$ & $\begin{array}{l}0 \\
\stackrel{1}{0}\end{array}$ & $\vec{z}$ & $\stackrel{\stackrel{L}{N}}{\stackrel{0}{0}}$ & $\begin{array}{l}N \\
m \\
0 \\
m \\
m \\
0 \\
0\end{array}$ & 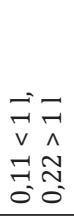 \\
\hline 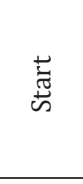 & $\begin{array}{l}\text { O̊ } \\
\text { ¿ }\end{array}$ & 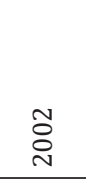 & 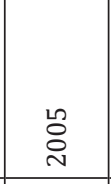 & 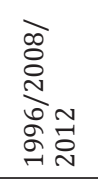 & $\stackrel{m}{\stackrel{\leftrightarrow}{̊}}$ & $\begin{array}{l}0 \\
\stackrel{1}{0}\end{array}$ & $\begin{array}{l}\stackrel{\circ}{\infty} \\
\stackrel{-}{\sim}\end{array}$ & $\stackrel{\text { L }}{\stackrel{\leftrightarrow}{\leftrightarrow}}$ & ஓ్ & 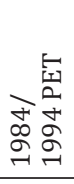 \\
\hline 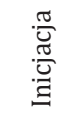 & $\stackrel{\text { L }}{\stackrel{0}{0}}$ & ঃ & 广্் & 1 & নু & $\underset{⿱ 丶}{\stackrel{+}{S}}$ & $\begin{array}{l}\stackrel{\circ}{\infty} \\
\stackrel{-}{\sim}\end{array}$ & $\stackrel{m}{\stackrel{\Xi}{d}}$ & ڤ్ & 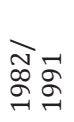 \\
\hline 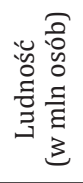 & $\stackrel{m}{\leftrightarrow}$ & $\begin{array}{l}0 \\
\text { si }\end{array}$ & $\stackrel{m}{\rightarrow}$ & $\stackrel{5}{5}$ & $\underset{\infty}{\sim}$ & $m$ & $m_{0}^{m}$ & $\begin{array}{l}\infty \\
\sigma^{\infty}\end{array}$ & L & L2 \\
\hline $\begin{array}{l}0 \\
\sum_{0}^{0} \\
\tilde{\Xi} \\
\Sigma\end{array}$ & $\begin{array}{l}\frac{\pi}{0} \\
\frac{\pi}{3} \\
0 \\
0 \\
0\end{array}$ & 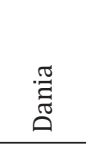 & 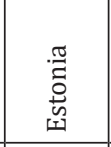 & 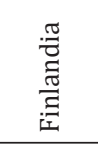 & 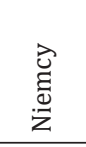 & 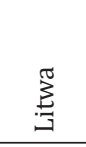 & 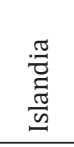 & $\begin{array}{l}\pi \\
\frac{\pi}{0} \\
\frac{\pi}{0} \\
0\end{array}$ & $\begin{array}{l}\frac{\pi}{00} \\
0 \\
3 \\
0 \\
z\end{array}$ & 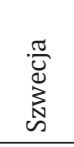 \\
\hline 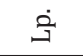 & - & $N$ & $m$ & $\psi$ & L & 0 & $\wedge$ & $\infty$ & $a$ & $\stackrel{\sim}{\circ}$ \\
\hline
\end{tabular}


stacjach kolejowych i w urzędach. RVM wymagają konserwacji i czyszczenia ze względu na styczność z odpadami i resztkami.

Maszyny RVM nie są obowiązkowe w działaniu systemu depozytowo-zwrotnego, można wyobrazić sobie system działający na podstawie zwrotu opakowań do sklepu, specjalnego punktu odbioru w kontenerach lub przy zakupie np. napojów - co również generuje koszty i utrudnienia. Automatyzacja zbioru odpadów opakowaniowych, jak wskazuje doświadczenie - por. tabela 2, jest najskuteczniejszym sposobem walki z odpadami. Ich zaletą jest zbiórka odpadów praktycznie niewymagających dalszej segregacji, łatwiejszych do recyklingu.

System depozytowo-zwrotny składa się z wielu ogniw, butelkomat to tylko brama, wejście do systemu. Na podstawie lektury raportów dotyczących działania takich systemów (np. System kaucyjny. Fakty i mity, 2019) można zauważyć dwie zasadnicze warstwy działania systemu. Pierwsza z nich to elementy okołosystemowe - bezpośrednie otoczenie wpływające na działanie systemu, w skład którego wchodzą podmioty i instytucje regulujące rynek i odpowiedzialne w kwestiach polityki ochrony środowiska i stanowienia prawa.

Wyróżniono elementy związane z legislacją i odpowiednim prawem, w którym ustanowione będą fundamenty działania systemu: zdefiniowane podmioty i ich odpowiedzialność materialna i organizacyjna, kwestie wyjaśniania sporów, ramy dla zawierania umów. Cele krajowe - to polityka gospodarowania odpadami uzupełniona o nowe cele zgodnie ze standardem SMART (Walczak, 2014). Kolejne są przepisy szczegółowe, wiążące, regulujące i synchronizujące działanie systemu z systemem podatkowym i finansowym oraz rachunkowością. System zgodności to prace służące standaryzacji opakowań, działania urządzeń i systemów informatycznych, szkolenia personelu obsługującego. Odpowiedzialność - to wyznaczenie zakresu obowiązków finansowych, karnych, organizacyjna uczestników systemu, zależna od podstaw prawnych, wyłonienie operatora systemu, przetargi na zakup i dostrojenie urządzeń (RVM) oraz obsługę systemu.

Wybór i dostosowanie systemu do krajowych i lokalnych uwarunkowań zbiórki odpadów - to praca naukowa i organizacyjna dostosowująca system do zachowani konsumenta i specyfiki rynku. Finansowanie - chodzi tu o podmioty finansujące działanie systemu podczas jego inicjacji, ustalenie zakresu finansowania z budżetu państwa i budżetów lokalnych w przypadku braku samofinansowania czy bilansowania się systemu (co jest częste), określenie wysokości kaucji. Monitoring scala klamrą działanie elementów okołosystemowych, powinien być przeprowadzany dwutorowo, tzn. monitoring danych z systemu - urządzenia RVM i raportowanie oraz ewaluacja i raportowanie uczestników systemu w celu jego doskonalenia i regulacji oraz efektywności i oddziaływania na środowisko przyrodnicze.

Elementy systemu sensu stricto to w pierwszej kolejności konsument, następnie automat zwrotny lub jego odpowiednik, pośrednik handlowy - punkty detaliczne: sklepy wielkopowierzchniowe i sklepy małe, organizacyjnie sieci handlowe pod własną marką lub franczyzowe. Pośrednik nalicza kaucję i realizuje zwroty kaucji, na jego terenie powinny być posadowione urządzenia RVM, na jego barkach spoczywać będzie zgłaszanie potrzeb serwisowych i sprawne działanie urządzeń. Nie musi być ich właścicielem, może zlecać ich instalację pośrednikom i operatorom. Producent i importer opakowań, zgodnie z utrwalonym w dyrektywach UE hasłem „zanieczyszczający płaci”, zobowiązany będzie ponosić koszty działania systemu do granic ustalonych rynkowo 
oraz odbierać w ustalonej części recyklat lub wprowadzać opakowania po oczyszczeniu do ponownego obiegu.

Tabela 3. Elementy okołosystemowe i systemowe DRS. Wstępne założenia

\begin{tabular}{|c|c|c|}
\hline Elementy okołosystemowe & $\begin{array}{c}\text { Elementy systemu } \\
\text { (rzeczowe, organizacyjne, ludzkie) }\end{array}$ & Koszty i zyski \\
\hline $\begin{array}{l}\text { Podstawa prawna } \\
\text { Cele krajowe } \\
\text { Przepisy szczegółowe } \\
\text { Systemy zgodności } \\
\text { Odpowiedzialność } \\
\text { Systemy zbiórki } \\
\text { Finansowanie } \\
\text { Monitoring }\end{array}$ & $\begin{array}{l}\text { Konsument } \\
\text { Automat zwrotny (infrastruktura) - } \\
\text { brama do systemu } \\
\text { Podmiot handlowy - pośrednik } \\
\text { Serwis automatów (często } \\
\text { producent) } \\
\text { Transport, magazynowanie } \\
\text { Producent/importer opakowań } \\
\text { Recykler - utylizacja/recykling } \\
\text { Centra i podsystemy } \\
\text { księgowo-rozliczeniowe } \\
\text { Główny operator i nadzorca } \\
\text { systemu }\end{array}$ & $\begin{array}{l}\text { Koszty: powierzchni i ochrony } \\
\text { obsługi pracowniczej, obsługi } \\
\text { księgowej, serwisowania } \\
\text { urządzeń, energii i mediów, } \\
\text { zakupu RVM } \\
\text { Zyski: niedobrane depozyty, } \\
\text { sprzedaż surowców, reklama, } \\
\text { trudno wymierne zyski } \\
\text { środowiskowe i estetyzacja } \\
\text { Dotacje }\end{array}$ \\
\hline
\end{tabular}

Źródło: opracowanie własne

Rycina 6. Schemat działania systemu depozytowo-zwrotnego

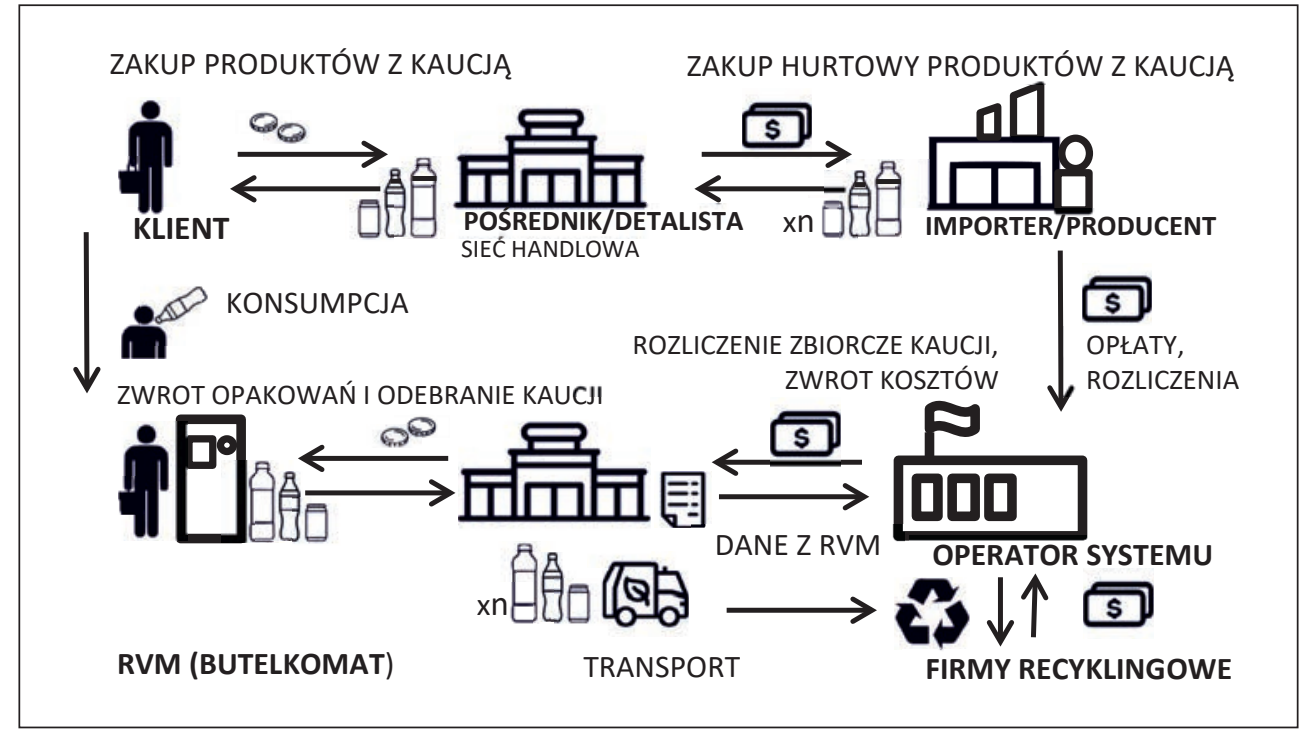

Źródło: opracowanie własne

W zależności od typu systemu najważniejszym podmiotem jest regulator (główny operator) systemu, to on dokonuje rozliczeń i naliczeń na podstawie danych z monitoringu. On zwraca koszty pośrednikom, w zależności od wyboru jest właścicielem surowców wtórych, które sprzedaje lub przekazuje do recyklingu. Duże znaczenie w systemie mają także centra księgowo-rozliczeniowe, które mogą być podmiotami zewnętrznymi na zasadzie outsourcingu. Ze względu na sposób organizacji systemów depozytowo-zwrotnych i rolę operatora systemu wyróżnić można trzy zasadnicze ich typy. 


\section{TYPY SYSTEMÓW DEPOZYTOWO-ZWROTNYCH}

\section{System scentralizowany - na przykładzie Norwegii}

Norweski system został zaimplementowany przez producentów napojów po wprowadzeniu przez rząd podatku od opakowań po napojach. System norweski ma mechanizm zmniejszania wysokości podatku wraz ze wzrostem wskaźników recyklingu (już od 25\%). W przypadku osiągnięcia recyklingu pojemników i butelek na poziomie 95\% producenci są z niego zwolnieni. Z odzyskanych butelek plastikowych w $92 \%$ uzyskuje się ponownie butelki. Centralny operator systemu to Norsk Resirk to Infinitum. Infinitum jest podmiotem non profit. Działa w imieniu branży przemysłu tworzyw sztucznych. W skład zarządu Infinitum wchodzą również przedstawiciele branży napojów i handlu detalicznego. Infinitum publikuje raport roczny, zawierający szczegółowe informacje na temat swoich przychodów, kosztów i wyników. W Norwegii działa 11,5 tys. punktów odbioru i 3,7 tys. automatów RVM (więcej na stronie https://infinitum.no/english).

\section{System zdecentralizowany - na przykładzie Niemiec}

Najwięcej takich rozwiązań spotyka się w Stanach Zjednoczonych w niektórych stanach. Na ogół są one mniej skuteczne niż systemy scentralizowane. Rozwiązania stosowane w Niemczech są bardziej wydajne, wynikają z tradycji porozumień branżowych. Spółka DPG Deutsche Pfandsystem GmbH (Niemiecki System Kaucyjny Sp. z o.o.) powstała z inicjatywy niemieckiego sektora handlu i przemysłu napojów. DPG ma prawnie uregulowane podstawy i zasoby organizacyjne do rozliczania depozytu między podmiotami uczestniczącymi w systemie. Uczestnicy nakładają na sprzedawane produkty (napoje) kaucję. DPG nie pełni jednak funkcji centralnej organizacji rozliczeniowej. Zamiast tego uczestnicy DPG mogą porozumiewać się między sobą. Zarząd DPG składa się z dwóch dyrektorów zarządzających, mianowanych z jednej strony przez reprezentację branży handlowej, z drugiej zaś - przez reprezentantów branży producentów napojów i opakowań.

Reprezentację po stronie branży handlowej objęło Stowarzyszenie Handlowe Niemiec (HDE). HDE to organizacja niemieckiego sektora detalicznego dla około 400 tys. niezależnych firm, zatrudniająca nieco poniżej $3 \mathrm{mln}$ pracowników i osiągająca ponad 420 mld euro rocznych przychodów. Druga strona reprezentowana jest przez BVE Federację Niemieckiego Przemysłu Spożywczego i Napojów - stowarzyszenie polityczne niemieckiego przemysłu spożywczego i napojów (więcej na stronie https://dpg-pfandsystem.de/index.php/en/).

\section{Systemy municypalne}

W Polsce za sprawą ruchów miejskich i aktywistów zgłaszane są projekty finansowane w ramach budżetów obywatelskich, środków prywatnych lub miejskich, mające na celu instalację butelkomatów - automatów RVM w przestrzeni miejskiej. Do tej pory automaty zainstalowano m.in. w Krakowie, Sosnowcu, Lublinie, Warszawie - z różnym skutkiem - często były zapchane lub nie działały. Propozycje i projekty dotyczą większości dużych miast. Są one odpowiedzią na rosnącą świadomość i oczekiwania 
społeczne dotyczące zagospodarowania odpadów w miastach. Wynikają także z obserwacji rozwiązań u sąsiadów Polski i wdrożeń systemów, np. na Litwie czy w innych miastach.

Doświadczenia i relacje z innych miast wskazują, że systemy municypalne, czyli pozbawione kaucji, nie sprawdzają się. Niewielka skala i wysokie koszty jednostkowe przy bardzo dużym zainteresowaniu konsumentów są mniej racjonalne niż spożytkowanie pieniędzy na inny sposób walki z odpadami. Niewątpliwie mają one pewną funkcję edukacyjną. W systemach municypalnych za dokonanie zwrotu klient otrzymuje różne gratyfikacje, np. bilety komunikacji miejskiej, punkty, doładowania telefonu, losy, talony itp.

\section{PodsumoWANIE - PERSPEKTYWY WDROŻEnIA DRS W POLSCE}

Państwa stosujące systemy automatów zwrotnych osiągnęły ponad 90-procentową stopę zwrotu opakowań PET, puszek i butelek szklanych. Konwencjonalny sposób segregacji zużytych opakowań według doświadczeń innych państw nie przekroczy 70\%. Doświadczenia ze Stanów Zjednoczonych - 10 stanów stosuje systemy DRS (RVM), tzw. bottle bill - niższe kwoty kaucji sprawiają, że zainteresowanie recyklingiem wśród konsumentów jest niższe.

Depozyt bądź kaucja jest mechanizmem zachęcającym do zwrotu butelek, należy go zatem ustalić na wysokim poziomie, aby zapewnić konsumentom poczucie, że warto zwrócić opakowanie czy butelki. Wysoki depozyt zachęca niestety do oszustw. Powszechny system DRS funkcjonujący w kilkunastu już krajach UE na podstawie ich doświadczeń okazuje się skuteczny. Jednak jego wprowadzenie do Polski wiązałoby się z dużym wyzwaniem prawnym i organizacyjnym, technicznym i finansowym.

Według słów płynących z Ministerstwa Środowiska: „Możliwość wprowadzenia systemu kaucyjnego $\mathrm{w}$ Polsce jest analizowana $\mathrm{w}$ ramach prac nad transpozycją tzw. pakietu odpadowego, tj. znowelizowanych dyrektyw z zakresu odpadów. System ten jest rozważany jako jeden ze skutecznych instrumentów osiągania wysokich poziomów zbierania opakowań i odpadów opakowaniowych, w tym i z tworzyw sztucznych" (informacje prasowe).

Kolejna strona istotna z punktu widzenia działania DRS to sieci handlowe, te poprzez swych rzeczników wypowiadają się ostrożnie, czekają na zmiany w prawie. Oficjalne komunikaty są enigmatyczne. Mniejsze kraje regionu - Czechy, Litwa i Estonia wdrożyły systemy butelkomatów. Według obszernego raportu firmy Deloitte koszt systemu w Polsce szacowany jest na 18-24 mld zł, z czego zakup butelkomatów to wydatek około 9,4 mld zł, szacowany na podstawie instalacji tych urządzeń w 120 tys. punktów odbioru (Analiza możliwości..., 2017).

System scentralizowany, oparty na sieciach handlowych i wysokich kaucjach, jest najlepszy ze względów logistycznych i kosztowych. Prowadzi do ujednolicenia typów opakowań i lepszej jakości surowca wtórnego. Na automaty zwrotne patrzeć należy z perspektywy całego systemu recyklingu i kosztów, a nie z punktu widzenia automatu. Automat jest tylko końcówką systemu in-out. Należy też mieć świadomość, że systemy DRS dotyczą niewielkiej części rynku odpadów, 45\% opakowań wprowadzanych na rynek w Polsce pochodzi z gospodarstw domowych. Z całej masy odpadów komunalnych to tylko 6\%. Koszty obecne w systemie DRS ponoszą producenci i importerzy opakowań danego typu. Są one relatywnie wysokie, jednak skuteczność systemu niweluje 
koszty środowiskowe i częściowo koszty po stronie gmin. Polskie społeczeństwo dojrzało mentalnie, ekonomicznie i organizacyjnie do wprowadzenia systemów recyklingu RVM. Wdrożenie DRS i RVM jest szansą na uporządkowanie kwestii recyklingu i zagospodarowania odpadów w naszym kraju.

Obecnie w Polsce budowana jest baza danych odpadowych. Jest to specjalny rejestr gromadzący podmioty wprowadzające do obrotu produkty, produkty w opakowaniach oraz gospodarujące odpadami. Od 1 stycznia 2020 roku baza jest rozbudowywana o moduł, dzięki któremu składanie niezbędnych sprawozdań może się odbywać wyłącznie w formie elektronicznej, ta zmiana ma być pierwszym krokiem na drodze do wprowadzenia nowoczesnego systemu DRS.

Wprowadzenie rozszerzonej odpowiedzialności producentów - dodatkowych opłat domaga się branża odpadowa - to również istotny element systemu DRS (rycina 6). Byłby to wstęp do wprowadzenia efektywnych systemów kaucyjnych. Według Forum Gospodarki Odpadami ściągniecie od przemysłu opakowaniowego nawet 2 groszy od opakowania mogłoby dać około 2 mld zł, które pokryłyby część kosztu zbiórki i zagospodarowania odpadów (Forbes, 2019).

Ministerstwo nie przesądziło jeszcze o szczegółach, jak będzie wyglądał system, rozważane są na razie niewielkie opłaty od każdego wprowadzonego na rynek opakowania. Systemy DRS, pełne lub mieszane, automatyczne (oparte na automatach) lub manualne (deponowanie opakowań w sklepie), mogłyby obniżyć kolejną opłatę - opłatę marszałkowską za składowanie odpadów. Należy nadmienić, że w systemach DRS odpady mają wyższą jakość - potencjał przerobowy, są cenniejszym surowcem niż śmieci sortowane samodzielnie w gospodarstwach domowych, co skutkuje skróceniem czasu i zmniejszeniem części kosztów ich dalszej obróbki.

Bardzo dużą zmianą jaką wprowadziłby system DRS, jest odciążenie gmin. Zbiórka odpadów komunalnych spoczywa dziś na barkach samorządów - to one organizują wywóz śmieci, zbierają opłaty i podpisują umowy, organizują przetargi z przedsiębiorstwami wywożącymi i utylizującymi śmieci. Systemy DRS mogłyby w większym stopniu odciążyć samorządy i pośrednio konsumentów od wciąż rosnących opłat. Problemem, który pojawia się wraz z dyskusją o systemie kaucyjnym, jest rozwój branży recyklingu i jej zdolność do przetwarzania odpadów. Problem ten istnieje nie tylko w Polsce, część posegregowanych w krajach zachodnich śmieci była eksportowana na dużą skalę do Chin, gdzie były one przetwarzane lub składowane. Prawo chińskie zabrania od 2019 roku importu odpadów, co obnaża fakt, że kłopot z nadmiarem odpadów i ich zagospodarowaniem mają dziś wszyscy.

\section{Literatura \\ References}

Analiza możliwości wprowadzenia systemu kaucyjnego dla opakowań. Opracowanie eksperckie. Deloitte (2017). Pozyskano z https://sdr.gdos.gov.pl/Documents/GO/Ekspertyzy/

Badcock, B. (2002). Making Sense of Cities. A Geographical Survey. London. Arnold.

Balcers, O., Brizga, J., Moora, H., Raal, R. (2019). Deposit Return Systems for Beverage Containers in The Baltic States. Riga: Green Liberty.

Beatley, T. (red.) (2012). Green Cities of Europe. Global Lessons on Green. Washington: Island Press.

Chakrabarti, T. (2014). Emergence of Green Technologies Towards Sustainable Growth. W: M.H. Fulekar, B. Pathak, R.K. Kale (red.). Environment and Sustainable Development. New Delhi, Heidelberg, New York, Dordrecht, London: Springer. doi: 10.1007/978-81-322-1166-2 
CM Consulting Inc. Deposit Systems For One-Way Beverage Containers: Global Overview (2016). Pozyskano z https://www.cmconsultinginc.com

Cordle, M., Elliott, L., Elliott, T., Kemp, S., Sherrington, Ch., Woods, O. (2019). A Deposit Refund System for the Czech Republic. Final Report. Eunomia Research \& Consulting Ltd. Pozyskano z https://www.eunomia.co.uk/reports-tools/deposit-refund-system-czech-republic/

Davies, P. (2017). Report for the Auckland Council. Cost-benefit analysis of a Container Deposit Scheme. Sapere Research Group.

Declaration of the Circular Plastics Alliance (2019, 1 grudnia). Komisja Europejska. Pozyskano z https://ec.europa.eu/docsroom/documents/36361

Dyrektywa Parlamentu Europejskiego i Rady (UE) 2018/849 z dnia 30 maja 2018 roku zmieniająca dyrektywy 2000/53/WE w sprawie pojazdów wycofanych z eksploatacji, 2006/66/ WE w sprawie baterii i akumulatorów oraz zużytych baterii i akumulatorów i 2012/19/UE w sprawie zużytego sprzętu elektrycznego i elektronicznego.

Dyrektywa Parlamentu Europejskiego i Rady (UE) 2018/850 z dnia 30 maja 2018 roku zmieniająca dyrektywę 1999/31/WE w sprawie składowania odpadów.

Dyrektywa Parlamentu Europejskiego i Rady (UE) 2018/851 z dnia 30 maja 2018 roku zmieniająca dyrektywę 2008/98/WE w sprawie odpadów.

Dyrektywa Parlamentu Europejskiego i Rady (UE) 2018/852 z dnia 30 maja 2018 roku zmieniająca dyrektywę 94/62/WE w sprawie opakowań i odpadów opakowaniowych.

Dyrektywa Parlamentu Europejskiego i Rady (UE) 2019/904 z dnia 5 czerwca 2019 roku w sprawie zmniejszenia wpływu niektórych produktów z tworzyw sztucznych na środowisko.

Fletcher, D., Hogg, D., Eye, M., Elliott, T., Bendali, L. (2012). Examining the Cost of Introducing a Deposit Refund System in Spain. Eunomia Research \& Consulting Ltd. Pozyskano z https:// www.eunomia.co.uk/reports-tools/examining-the-cost-of-introducing-a-deposit-refund-system-in-spain/

Forbes (2019, 1 grudnia). Zostanie wprowadzona kaucja za plastikowe butelki. Pozyskano z https://www.forbes.pl/gospodarka/oplata-za-wprowadzanie-na-rynek-opakowan/bsl99tk

Hanaki, K. (2002). Environmental loading of resource and heat recovery. W: F. Moavenzadeh, K. Hanaki, P. Baccini (red.). Future Cities: Dynamics and sustainability. Springer-Science + Business Media, B.V. ISBN 978-94-010-0365-0 (e-book).

Hołuj, A. (2018). Ekonomiczne i ekologiczne efekty zewnętrzne w planowaniu przestrzennym. Łódź: Wydawnictwo Uniwersytetu Łódzkiego.

Moir, E., Moonen, T., Clark, G. (2014). What Are Future Cities? Origins, Meanings And Uses. Government Office for Science. Pozyskano z https://www.gov.uk/government/publications/future-cities-origins-meanings-and-uses

Report From The Commission To The European Parliament, The Council, The European Economic And Social Committee And The Committee Of The Regions on the implementation of the Circular Economy Action Plan (2019). Pozyskano z https://ec.europa.eu/commission/ sites/beta-political/files/report_implementation_circular_economy_action_plan.pdf

Rogers, R. (1997). Cities for a Small Planet. London: Faber \& Faber.

Rudewicz, J. (2019). Metabolizm i energia w mieście. Przegląd Uniwersytecki. Pismo Uniwersytetu Szczecińskiego, 4-6, 21-24.

System kaucyjny. Fakty i mity (2019, 1 grudnia). Deloitte. Pozyskano z https://www2.deloitte. $\mathrm{com} / \mathrm{pl} / \mathrm{pl} / \mathrm{pages} / \mathrm{press}$-releases/articles/butelki-plastikowe-system-kaucyjny.html

The History of Reverse Vending 1920 to 2014 (2013) (2019, 1 grudnia). Reverse Vending News. Pozyskano z https://reversevending.wordpress.com/2013/09/16/the-history-of-reversevending-1920-to-2013/

The New Plastics Economy. Rethinking the future of plastics NPE (2016) (2019, 1 lipca). Pozyskano z http://www3.weforum.org/docs/WEF_The_New_Plastics_Economy.pdf

Ustawa o odpadach z dnia 14 grudnia 2012 roku (Dz.U. z 2019 r. poz. 701).

Walczak, R. (2014). Podstawy zarządzania projektami - metody i przykłady. Warszawa: Difin.

Ween, C. (2012) A Global and Sustainable Capital City. W: T. Beatley (red.). Green Cities of Europe. Global Lessons on Green Urbanism. Washington, Covelo, London: Islandpress.

Jacek Rudewicz, dr inż., Uniwersytet Szczeciński, Instytut Gospodarki Przestrzennej i Geografii Społeczno-Ekonomicznej. Jest adiunktem w Zakładzie Badań Miast i Regionów. Ukończył kierunek geografia ze 
specjalnością geografia społeczno-ekonomiczna, kierunek zarządzanie i marketing oraz ekonomia. W pracy naukowej zajmuje się studiami miejskimi, rozwojem zrównoważonym, rozwojem regionalnym, teorią systemów.

Jacek Rudewicz, PhD Eng., University of Szczecin, Institute of Socio-Economic Geography and Spatial Management. He has graduated from Geography with a specialisation in socioeconomic geography, he also holds a degree in management and marketing and economics. He is an assistant professor in Regional and Urban Studies Unit. His research interests focus on urban studies, sustainable development, regional development, systems theory.

ORCID: https://orcid.org/0000-0002-2659-4754

\section{Adres/address:}

Uniwersytet Szczeciński

Instytut Gospodarki Przestrzennej i Geografii Społeczno-Ekonomicznej

Zakład Badań Miast i Regionów

ul. A. Mickiewicza 18, 70-383 Szczecin, Polska

e-mail: jacek.rudewicz@usz.edu.pl 